\title{
Graphic Organizers as Effective Methods in Teaching Classroom English
}

\section{Zamira Kalmamatova1, Ababakir Shamurzaev², Raikan Ysmailova ${ }^{3}$, Karamat Belekova1, Dilrabo Ahmadalieva ${ }^{4}$, Nurzat Sartbaeva ${ }^{2}$, Nargul Bekmuratova², Ykyval Moldoeva2, Nurgul Kidiralieva², Zhypargul Abdullaeva ${ }^{5^{*}}$}

${ }^{1}$ Department of English Teaching Methods, Osh State University, Osh, Kyrgyzstan

${ }^{2}$ Department of English Teaching Methods, Osh State Pedagogical Institute of Humanities, Osh, Kyrgyzstan

${ }^{3}$ Department of Social-Humanitarian Disciplines, Osh State University, Osh, Kyrgyzstan

${ }^{4}$ Department of English Grammar, Faculty of Foreign Languages, Andijan State University, Andijan, Uzbekistan

${ }^{5}$ Science and Research Department, Osh State University, Osh, Kyrgyzstan

Email: *jypar.science@oshsu.kg

How to cite this paper: Kalmamatova, $Z$. Shamurzaev, A., Ysmailova, R., Belekova, K., Ahmadalieva, D., Sartbaeva, N., Bekmuratova, N., Moldoeva, Y., Kidiralieva, N., \& Abdullaeva, Z. (2020). Graphic Organizers as Effective Methods in Teaching Classroom English. Open Journal of Modern Linguistics, 10, 459-467.

https://doi.org/10.4236/ojml.2020.105027

Received: August 18, 2020

Accepted: September 27, 2020

Published: September 30, 2020

Copyright $\odot 2020$ by author(s) and Scientific Research Publishing Inc. This work is licensed under the Creative Commons Attribution International License (CC BY 4.0).

http://creativecommons.org/licenses/by/4.0/

\section{(c) (i) Open Access}

\begin{abstract}
This article is investigating a variety of techniques in teaching English such as class discussions, presentations, small group discussions, pair work, group work, special projects, and task-oriented assignments. It is beyond the argument that different kinds of methods and teaching techniques should be tried to make the teaching better. It depends on teachers how they make good use of methodologies of teaching English. In this paper, various methods such as "Mind map", "Venn diagram", and "Brainstorming", approaches and their techniques in teaching students are described and applied as an ESL instructor's tool. Students list and categorize the concepts and ideas relating to a topic in these activities. It is important to note that all the above techniques have the common goal of education - to teach students to communicate in English, as well as participate in the development of individual students.
\end{abstract}

\section{Keywords}

Communication, Relationship, Resources, English Language, Teaching, Graphic Organizers

\section{Introduction}

Many new communicative methodologies in teaching English have emerged into practice in recent years and are intended for personal and recreational uses (Littlewood, 2014). Teaching English requires communicative competence in a foreign language evaluation approach as well as in the classroom practice in many 
different contexts (Savignon, 2017). However, English language teaching is looking for new approaches to address the range and level of English proficiency required for participation in today's global community (Fleckenstein et al., 2016).

The methods by which students taught must have some effects on their motivations. If they find them boring, they will probably become not motivated, whereas if they have confidence in the method, they can be motivated more. Motivated students will probably succeed despite which method is used. It is also true that different students are more or less sympathetic to any particular method depending upon their expectations. Teachers can easily recall students who felt that there was not enough grammar or enough conversation (depending on students' interests at the time). The term "critical thinking" was commonly used in the research literature, where the methods and conceptions in teaching were underlined (Pithers \& Soden, 2000). Critical thinking techniques portfolio may enhance and improve the metacognitive knowledge and skills of students in English classes (Farahian \& Avarzamani, 2018).

The mind map is a useful technique in the critical thinking method, which allows students to create complex topics by graphical representation of constituent subtopics and related themes (Kernan et al., 2018). Choosing of mind mapping tool largely depends on the purpose or aim of the used tool, and the tool may offer educators potentially complementary functions (Davies, 2011). Mind map as a graphic organizer strategy develops the spirit of cooperation and teamwork among students, particularly when using group mind maps.

The Venn diagram is an easily remembered graphic illustration where the center is representing content and context individually, and two circles in edges are an interaction between these circles (Otto \& Everett, 2013). Two types of Venn diagrams commonly used such as linear and stack with advantages focused on the development of hierarchy concepts, students, communication practice, and exercise abilities (Landøy et al., 2020). Students' critical thinking indicated by fluency, flexibility, and originality of ideas mostly promoted via brainstorming (Van de Kamp et al., 2016). Participating in a brainstorming session during classes provokes cognitive facilitation in students (Heslin, 2009). Using a brainstorming in a group can be more beneficial after individual idea generation in students due to initially generated ideas setting to the topic title and contents (Ritter \& Mostert, 2018). It was found, that graphic organizers exhibited wide effect on academic success rather than traditional teaching methods (Kansizoğlu, 2017). Furthermore, teachers recommended using these techniques in teaching various aspects in English; change the traditional method of teaching, and developing visual thinking skills in all aspects of English and other subjects using mind maps and present new methods in teaching vocabulary.

In this work we analyzed student's confidence and motivations in learning English by using the critical thinking methods "Mind map", "Venn diagram", and "Brainstorming", approaches. Moreover, the student's confidence in the method is largely in the hands of the most important factor affecting intrinsic motivation, the teacher. 


\section{Research Methods}

Detailed summaries of various language teaching methods developed and used over the past century, including Grammar Translation, the Direct, the Audiolingual, the Community Language Teaching, Suggestopedia, the Natural Approach methods. In this article we described the community language learning methods which are not just attempting to teach students how to use another language communicatively but also tries to encourage the student to take increasingly more responsibility for their learning and to "learn about their learning", so to speak. Learning in a non-defensive manner is considered very important, with teachers and students regarding each other as a "whole person" where intellect and ability are not separated from feelings. The initial struggles with learning the new language addressed by creating an environment and mutual support, trust, and understanding between both learner-clients and the teacher-counselor.

The language learning community used methods, which are involving some of the following features:

1) Students are considered as "learner-clients" and the teacher as a "teacher-counselor".

2) A relationship of mutual trust and support is considered essential to the learning process.

3) Students are permitted to use their native language, provided with translations from the teacher, which they then attempt to apply.

4) Grammar and vocabulary are taught inductively.

Students are encouraged to express not only how they feel about the language, but also how they feel about the learning process, to which the teacher expresses empathy and understanding.

\section{Results and Discussions}

A variety of activities can be included (for example, focusing on particular grammar or pronunciation point, or creating new sentences based on the recordings/transcripts). The change of techniques brought by the English schools expected to make a positive contribution to the field of foreign language teaching. We have gained practical experience of teaching and the issues it entails during the work in the faculty of FL and the techniques obtained within the work experience at the university implemented.

An experiment with different methods and their techniques was conducted to see whether they were effective or not with the students. Now schools are trying to change the teaching techniques. Still then sometimes, we ended up using the traditional techniques of the Grammar Translation method rather than Direct or Communicative methods. Sometimes, without knowing the methods, even their techniques, or any teachers' training, the teachers were following the Grammar Translation method and its techniques. Few teachers were trying to invent new ways of teaching, which fall under the Communicative Language Teaching ap- 
proach. This is recommended for in-service teacher training to enhance the proficiency of the teachers and use their potentials by familiarizing them with modern trends of teaching.

Various methods of teaching such as "Mind map", "Venn's diagram", and "Brainstorming", approaches and their techniques in teaching students are described in this paper. It was difficult and not advisable to follow certain techniques exactly as prescribed in different methods while teaching. Good teachers always adapt the techniques to suit the learning atmosphere. The lesson theme "NO PLACE LIKE HOME" includes pre-activity and while-activities a shown below:

\subsection{Pre-Activity}

Here students should answer the question and perform the following tasks:

1) Why do people go to live abroad?

2) Make a list of reasons (it is desirable to use a mind map as shown in Figure $1)$.

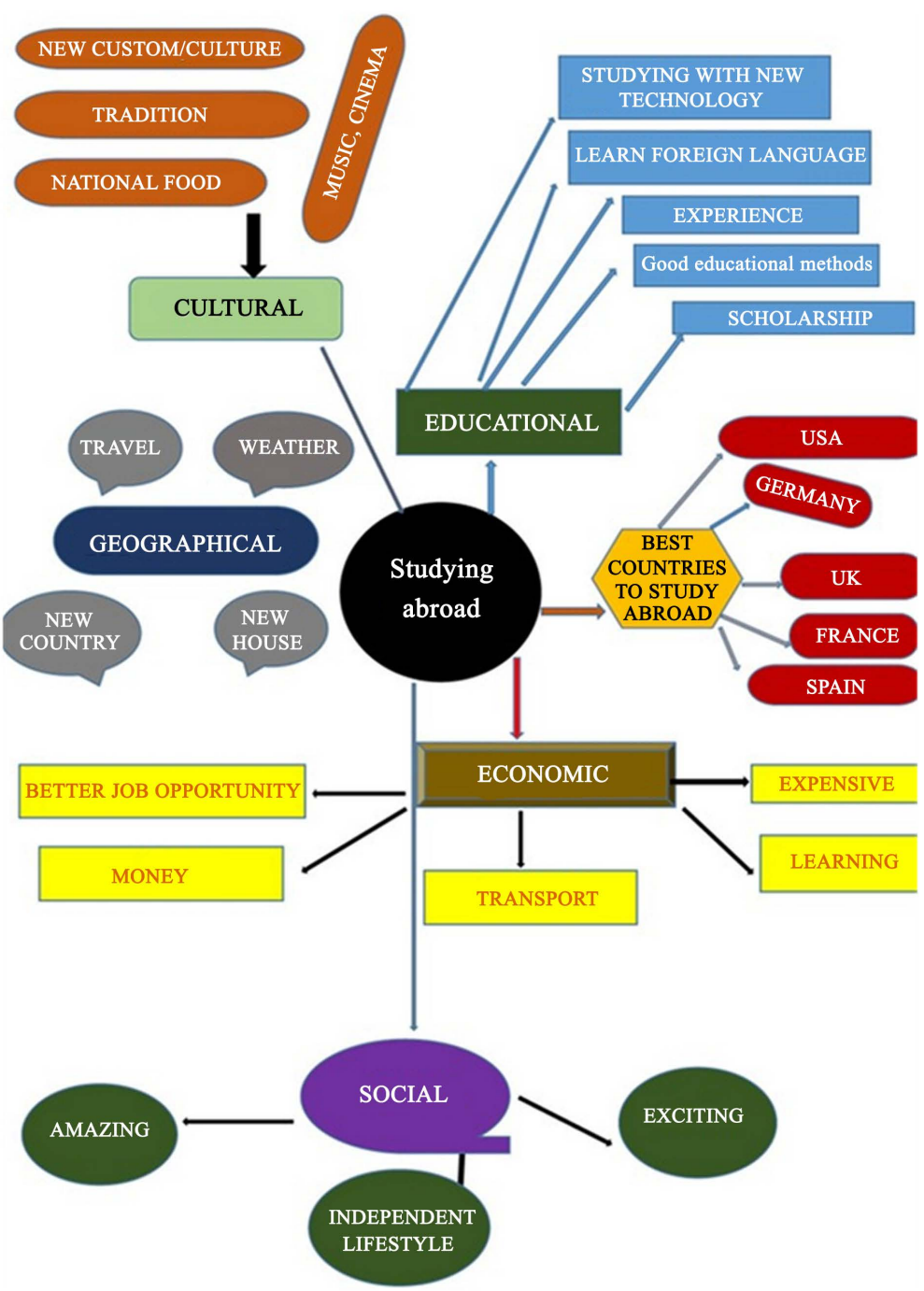

Figure 1. Mind map made by students during pre-activity. 


\subsection{While Activity}

In this activity, students should:

1) Read the text (Text 1 and Text 2)

2) Divide into two groups (group A and group B), where Group A students should read and understand about Ian in the text, and the Group B students should read and understand about Thomas in the text.

\section{Text 1: THOMAS GREED IN KOREA}

I'm part of a group now. The only difference is I have brown hair and blue eyes'. Says Thomas Greed, in eleven-year-old originally from Boston, Massachusetts.

Thomas says: These days I'm really into soccer. Soccer is a really big deal here ever since they hosted the 2002 World Cup. But Dad doesn't get it. I wasn't a soccer fan either when I first came to Seoul six years ago. Like my dad, I was a big basketball fan-still am-watching all the games Dad taped, cheering for the Celtics. But now, I and my friends play soccer all the time. It is hard not to get addicted. My best friend Dong-won and I cut out photos of David Beckham and trade them like baseball cards.

My dad is an officer in the US Army, but he was not always such a big shot. He had "tours of duty", which means he has had to move around whether he liked it or not. He has lived in places like Germany, Vietnam, and Saudi Arabia. My mom and I always stayed back in Boston. She is a scientist. But then my dad and my big brother Patrick both got transferred to Korea-Patrick is ten years older than me, and he is in the Army, too. So, our whole family moved over. Seoul is cool. There are millions of places called "PC rooms" where you can play tons of Internet games. The city is a lot bigger than Boston, too, and way more crowded and busier. I did not like that at first. I could not understand what anyone was saying, and people here do not always smile at strangers as they do back in the US. I felt lonely like I was in the middle of nowhere.

Life is different here. Most homes don't have radiators-the heat comes up through the floor instead. It is done like this because most Koreans eat cross-legged on floor mats. It is easier than using chairs, but it gives my father leg cramps. It is also normal to roll out mattresses and sleep on the floor.

That is how I sleepover at Dong-won's house. Dong-won's great and helped me a lot when I first started elementary school here. I was five and did not know anything or anybody and was pretty scared. I even made my dad wait for me in the next room. Now I can speak Korean fluently, but learning Chinese characters stinks. I always do badly on those tests. I can eat spicy foods like Kimchee; I have read a lot of Korean books and stories, which I like.

What I miss most are American comics. I know it is stupid "because there are lots of comics here, but they are different. They don't have superheroes like Spiderman, who always has something cool to say, even when the bad guy is beating him up. Also, I wish basketball was more popular. I love soccer but no one understands how awesome a slam dunk" can be. But I like living here. The people are here really nice, and maybe I will be a translator one day... or even better, a 
great soccer player like David Beckham.

\section{Text 2: IAN WALKER-SMITH IN CHILE}

Ian Walker-Smith comes from Crewe, England, but now lives and works in Chile. He has married a Chilean woman, Andrea, and works for a European astronomical agency in the town of Paranal. Ian says: "I work shifts of eight days in Paranal and get six to rest at home-in my case, the mining town of Antofagasta, a harrowing from two-hour drive away on the coast. It takes a real toll, being so far from Andrea. I miss her when I am away”.

I work at Paranal Observatory, where every night the boundaries of our universe are probed by four of the world's largest telescopes. I am part of a 12-strong IT team which looks after everything from satellite ground stations to desktop support. My role is to make sure the computers run 24/7. As Paranal is in the middle of nowhere-up a mountain in desert-the sky truly amazing. As we are $2600 \mathrm{~m}$ above sea level, I easily get puffed when I am exercising and each time I arrive for a week on shift, I can't think straight or fast for the first day or so.

I decided to move to Chile four years ago when I was a 25-year-old with itchy feet (and wanted to get out of the way of an ex-girlfriend!). I was working for Littlewoods Home Shopping Group, and one day a colleague pointed out this job in Chile. We both thought it would be a good idea, but I was the one who put a $\mathrm{CV}$ together.

Landing at Santiago airport was my first experience of language being such a barrier. I couldn't speak more than a handful of words in Spanish, and would you believe that my baggage had got lost! So, my first couple of hours in Chile was spent trying to locate my missing possessions. Today I can order food in restaurants and argue with mechanics about my car, but I cannot make myself understood on any deeper level. I can't get my thoughts across as a native speaker could. Andrea speaks pretty good English, and we converse in what we call "Spanglish"-at least we can understand each other.

Antofagasta, the town where we have made our home, was once described in a Chilean advertising campaign as the "Pearl of the North". Let's just say that it is hardly a tourist destination (which is pretty much what you would say about my hometown, Crewel!). Antofagasta and its surrounding mines are said to make more money for Chile than another city. During my time here, some money has been put back into the city. The municipal beach has been much improved. We now have a pleasant walkway along the seafront.

Even after 4 years, I don't feel I belong. Over Christmas I went back to the UK for a month's holiday-on landing at Heathrow, I felt at home straight away. What I miss most is greenery. My own culture still fits me like the winter gloves I left behind when I came to work in the desert sun. Shame I cannot say the same as my old winter trousers...

\subsection{Post Activity}

Here students in group A and B should answer to the questions about Ian and 
Thomas:

1) Where did he go to live abroad? Why?

2) How long has he been there?

3) What does he do there?

4) What do you learn about his family?

5) What is the new hometown like?

6) Have there been any difficulties?

7) In what ways is the "in the middle of nowhere"?

8) Does he feel at home in his new home?

9) What does he like and dislike about his new life?

10) What does he miss?

After that, students should complete the Venn's Diagram as shown in Figure 2 (finding differences and similarities between Tom and Ian in the text).

\section{Similarities:}

1) Both of them migrants.

2) The native language is English.

3) Both of them had a language barrier when they came for the first time to another country.

4) They live abroad, but they missed their own country, culture.

5) They had to learn another language.

6) They like the country where they live now.

7) They got used to living in another life.

\section{Differences: Thomas Greed in Korea:}

1) He is 11 years old.

2) Thomas from Boston, Massachusetts.

3) He is single.

4) He moved to Korea.

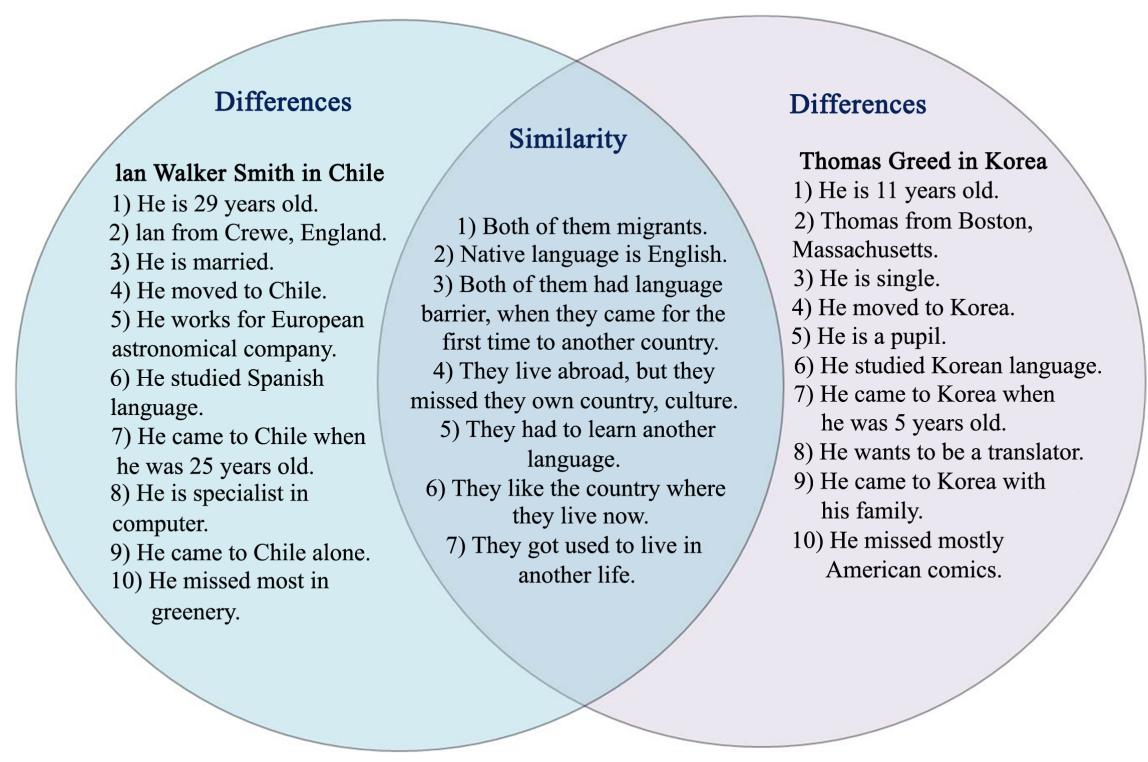

Figure 2. Venn's diagram. 
5) He is a pupil.

6) He studied the Korean language.

7) He came to Korea when he was 5 years old.

8) He wants to be a translator.

9) He came to Korea with his family.

10) He missed mostly American comics.

Differences: Ian Walker Smith in Chile

1) He is 29 years old.

2) Ian from Crewe, England.

3) He is married.

4) He moved to Chile.

5) He works for the European astronomical company.

6) He studied the Spanish language.

7) He came to Chile when he was 25 years old.

8) $\mathrm{He}$ is a specialist in computer.

9) He came to Chile alone.

10) He missed most of the greenery.

Students made a list of the disadvantages of moving abroad. Then for every disadvantage $(-)$, they try to find an advantage $(+)$. After students have worked on listing the advantages and disadvantages of living abroad, one gives a reason not to live abroad, and the other replies with the relevant advantage. For example, the language barrier is a problem if you do not speak the language. Yes, but (on the other hand) it gives you a great opportunity to learn a new language. It was challenging and exciting for students, as they were foreigners (they were Turkish students). These strategies work perfectly in English classes because they make social arrangements, solve problems, and come to conclusions together.

\section{Conclusion}

In conclusion, using the graphic organizers in English teaching classroom offers a tremendous amount of benefit in language acquisition. The integration of creativity and teamwork improves students' thinking and practical language skills. This ensures and fulfills an effective result for English language teaching. It would be better to integrate several methods by combining their best sides for students. We can say that the early formation of an integrated method incorporates the best elements of different methods.

\section{Conflicts of Interest}

The authors declare no conflicts of interest regarding the publication of this paper.

\section{References}

Davies, M. (2011). Concept Mapping, Mind Mapping and Argument Mapping: What Are the Differences and Do They Matter? Higher Education, 62, 279-301.

https://doi.org/10.1007/s10734-010-9387-6 
Farahian, M., \& Avarzamani, F. (2018). The Impact of Portfolio on EFL Learners' Metacognition and Writing Performance. Cogent Education, 5, 21. https://doi.org/10.1080/2331186X.2018.1450918

Fleckenstein, J., Leucht, M., Pant, H. A., \& Köller, O. (2016). Proficient beyond Borders: Assessing Non-Native Speakers in a Native Speakers' Framework. Large-scale Assessments in Education, 4, 1-19. https://doi.org/10.1186/s40536-016-0034-2

Heslin, P. A. (2009). Better than Brainstorming? Potential Contextual Boundary Conditions to Brainwriting for Idea Generation in Organizations. Journal of Occupational and Organizational Psychology, 82, 129-145. https://doi.org/10.1348/096317908X285642

Kansizoğlu, H. B. (2017). The Effect of Graphic Organizers on Language Teaching and Learning Areas: A Meta-Analysis Study. Education and Science, 42, 139-164. https://doi.org/10.15390/EB.2017.6777

Kernan, W. D., Basch, C. H., \& Cadorett, V. (2018). Using Mind Mapping to Identify Research Topics: A Lesson for Teaching Research Methods. Pedagogy in Health Promotion, 4, 101-107. https://doi.org/10.1177/2373379917719729

Landøy, A., Popa, D., \& Repanovici, A. (2020). Teaching Learning Methods. In Collaboration in Designing a Pedagogical Approach in Information Literacy (pp. 137-161). Springer Texts in Education, Cham: Springer.

https://doi.org/10.1007/978-3-030-34258-6

Littlewood, W. (2014). Communication-Oriented Language Teaching: Where Are We Now? Where Do We Go from Here? Language Teaching, 47, 349-362. https://doi.org/10.1017/S0261444812000134

Otto, C. A., \& Everett, S. A. (2013). An Instructional Strategy to Introduce Pedagogical Content Knowledge Using Venn Diagrams. Journal of Science Teacher Education, 24, 391-403. https://doi.org/10.1007/s10972-012-9272-5

Pithers, R. T., \& Soden, R. (2000). Critical Thinking in Education: A Review. Educational Research, 42, 237-249. https://doi.org/10.1080/001318800440579

Ritter, S. M., \& Mostert, N. M. (2018). How to Facilitate a Brainstorming Session: The Effect of Idea Generation Techniques and of Group Brainstorm after Individual Brainstorm. Creative Industries Journal, 11, 263-277.

https://doi.org/10.1080/17510694.2018.1523662

Savignon, S. J. (2017). Communicative Competence. In J. I. Liontas, T. International Association, \& M. DelliCarpini (Eds.), The TESOL Encyclopedia of English Language Teaching (pp. 1-7). Hoboken, NJ: John Wiley \& Sons, Inc. https://doi.org/10.1002/9781118784235.eelt0047

Van de Kamp, M., Admiraal, W., \& Rijlaarsdam, G. (2016). Becoming Original: Effects of Strategy Instruction. Instructional Science, 44, 543-566. https://doi.org/10.1007/s11251-016-9384-y 